\title{
Stela and Fragments in the
}

Grand Egyptian Museum

Dr.Eman AbouZaid

Assistant Professor

Faculty of Archaeology, Qena

South Valley University, Egypt 



\section{Stela and Fragments in the Grand Egyptian Museum}

\section{Eman Abouzaid}

This paper is focusing on four funerary fragments, namely inventory numbers Sr. 14170 , 10322 , and Sr 10220, preserved in the Grand Egyptian Museum.

\section{I- The Stela (pl. (1))}

This stela ${ }^{1}$ Sr. 14170 is made of sandstone with following measures: $59.5 \mathrm{~cm}$ height, $38.3 \mathrm{~cm}$ width, $9 \mathrm{~cm}$ in thickness. it's upper lunette is completely weathered. Below is the deceased standing facing left with two arms raising in adoration pose. He wears a long pleated kilt, a broad collar and a wig with a heavy side-lock. Before him Osiris is shown in his usual form that his body is wrapped in a fitting linen that shows his ears and face to view. A tightly fitting skull cap enveloped his head, he holds the $w 3 s$ - sceptre of dominion with his two hands. Before him, there is one of the most frequently encountered epithets of the god Anubis is jmj-wt ${ }^{2}$.

1 For the stela, as a tearm, see K. Martin, LA VI, col. 1-6; R. Holzl,"Stela", in Oxford Ensyslopedia of Ancient Egypt III, Oxford, 2001, p. 319-324

${ }^{2}$ It occurs from the Old Kingdom until the Roman Period. It is first found in the 4th dynasty after which it becomes increasingly common . It is translated as "He who is in the place of embalmment", or He who is in the place of the mummy-wrappings ", The term wt does indeed refer to the bindings used for the body after mummification, and it would be appropriate to describe Anubis, who presided over the preservation of the body, see; Duquesne T., Jmjwt, UCLA Encyclopedia of Egyptology, 2012, Wb. I, 73; for further bibliography of this sign see, Leitz, Christian (ed.), Lexikon der ägyptischen Götter und Götterbezeichnungen. Vol. 1. Orientalia Lovaniensia Analecta 110. Dudley, MA, and Leuven: Peeters, 2002 ; Logan, Thomas, The origins of the Jmy-wt fetish. Journal of the American Research Center in Egypt 27,1990, pp. 61 - 69; RösslerKöhler, Ursula, Das Imiut: Untersuchungen zur Darstellung und 
Behind him his wife Mut is standing wearing a long tightfitting dress reaching to mid-calf with curled and braided wig. She raises her right hand in greeting pose into the deceased while her left is holding the ' $n h$ - singe. Behind her the third member of the Mampheic triad, Horus, is standing in the same previous pose. He wears a tripartite wig and a short kilt. The middle part displays the son Nekhet who erected the stela in the name of his father Pasahta standing with one arm extending towards his father in a respective pose while his left is extending beside. He wears a long limpid kilt upon a short one, broad collar and a wig with a heavy side-lock. Before him his father is setting on a low backed chair facing left wearing a long pleated kilt and a broad collar. Also, he wears a wig with a heavy side-lock and holds by his right Kherp-specter while his left is extending beside. Behind him his wife standing with her left arm raising towards her husband shoulder while her right is extending beside. She wears a long tight-fitting dress reaching to mid-calf, curled and braided wig.

Behind the son Nekhet his grandfather Raemaa is setting on a low backed chair facing right wearing a broad collar, a long pleated kilt, and a wig with a heavy side-lock. He holds by his right Kherp-specter while his left is extending beside. Behind him his wife standing with her right arm raising up while her left is extending beside. She wears a long tightfitting dress, curled and braided wig. Remarkably, all the names that recorded on this stela are not attested in Ranke, $P N$, this is attributed to the importance of this stela.

Bedeutung eines mit Anubis verbundenen religiösen Symbols. 2volumes. Göttinger Orientforschungen 4. Wiesbaden: Harrassowitz, 1975; Ibid, Imiut. In Lexikon der Ägyptologie, Vol. 3 (columns 149 - 150), ed. Wolfgang Helck, and Wolfhart Westendorf. Wiesbaden: Otto Harrassowitz, 1980 
The texts don't include any of the name of a reigning pharaoh which is one of the most helpful methods to date this kind of finds. Based on the respective paleography and epigraphy, this stela can be New Kingdome. Dating criteria is executed in all of the curled and braided wigs' a long pleated kilt'

\section{The Hieroglyphic inscriptions}

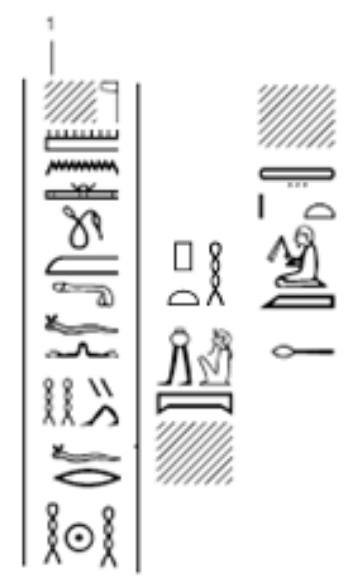

[dw3] ntr mn rwd m-b3h.f $n$ ḥhi.f $r$ hh Pth in $p t\left[p 3 s 3 h\left[t 3 m_{3}{ }^{c}\right.\right.$ hrw.

Adoring the god, I am fixed and steadfast before him, I will not cut of you for eternity, O Ptah who brings the sky [Pasah]ta, justified.

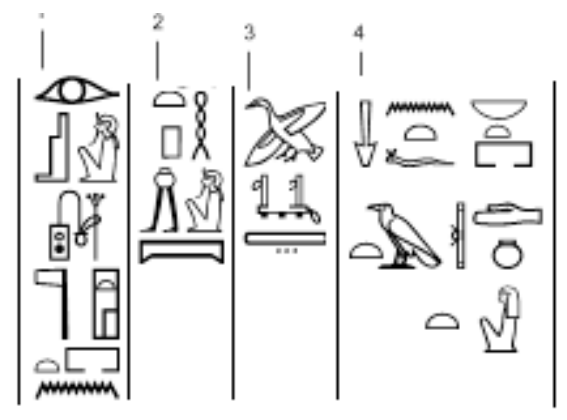

Wsir sš hwt ntr $n$ Pth in pt P3-s3hh-t3 snt.fnbt pr $t 3$ dnt. 
Osiris, the scribe of the temple of Ptah, who brings the sky, his daughter, lady of the house Tadent.

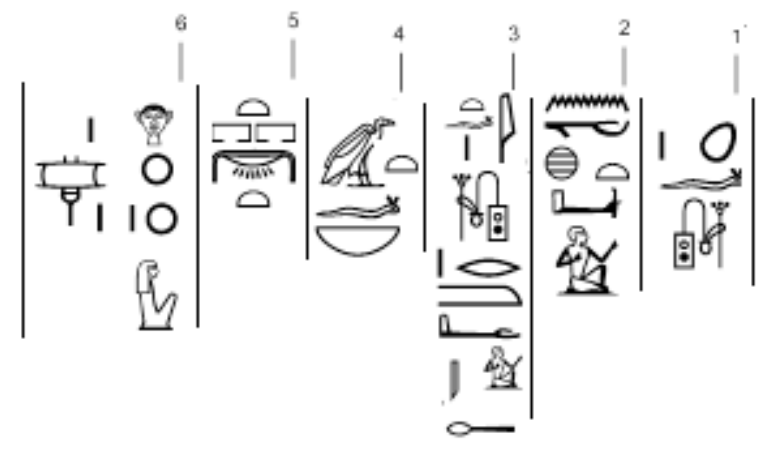

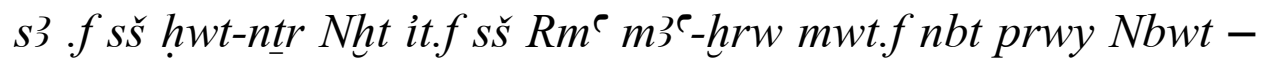
hr - sp-sn-spsn- $n f 3 w$.

His son, the scribe, Nekhet. His father, the scribe Ramea, justified. His mother lady of the two houses Nebwt-he sepsensepsen-nefaw.

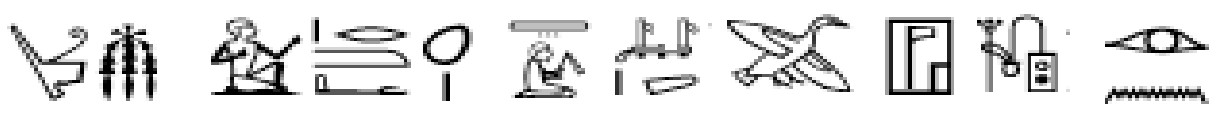

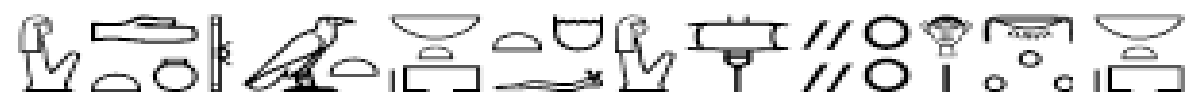

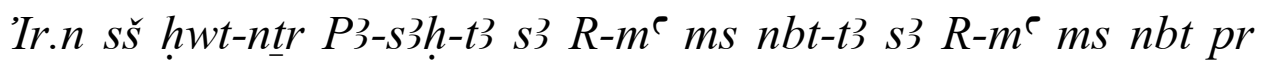
Nwbt -hrr-sp-sn sp-sn-nf3w hmt.f nbt pr T3-dnt.

It was consecrated into the scribe Pasahta son of Ramea, he was borne from lady of the house Nebwt- hersepsen sepsen- nefaw. His wife is lady of the house Tadent.

As can be realized from the preceding study, this stela was erected in the name of the scribe Pasahta who occupied the scribe office in the temple of Ptah by his son Nekhet. The last one follows his father in the same office. Also Pasahta had the same office after his father Ramea death. So, we are dealing with a family follows one another in the same office 
within the temple of Ptah. Therefore we can hear draw their family tree that not attested in Ranke, $P N$. as follows:

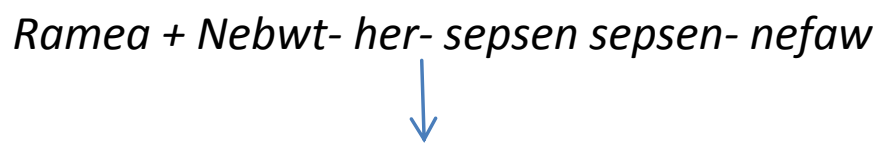

Pasahta+ Tadent

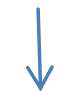

Nekhet

Based on the respective paleography and epigraphy, it can be dated to the New Kingdome, probably to the Ramesside period.

\section{II- The First Fragment (PI. (2))}

This fragment Sr. 10322 is made of limestone with following measures: $19.5 \mathrm{~cm}$ height, $6.5 \mathrm{~cm}$ width, $21 \mathrm{~cm}$ in thickness. The surface is slightly weathered, it's upper part is lost. The provenance is not known. The panel displays a seating figure maybe is the owner of the stela on the throne receiving the adoration that presented by his wife who appears standing on the left side, wears a long tight-fitting dress reaching to midcalf. The Offering table is piled with various kinds of provisions like oxen limbs, beer vessel and bread slices shape. Underneath the table, to the right, is a large ewer and to the left is a blooming lotus flower with jars of wine. The design of the stela is typical of the New Kingdome. The bottom part is carved with three horizontal incised lines as follows:

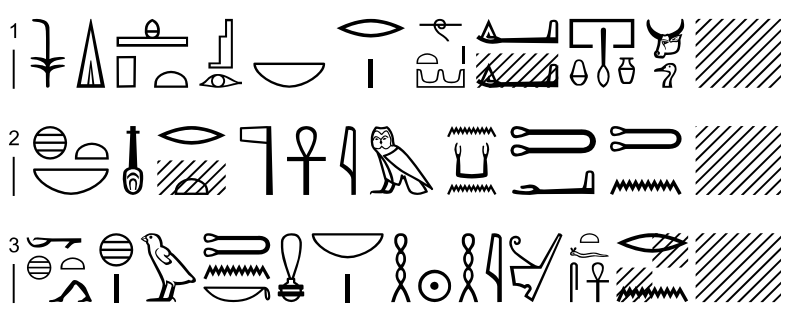


1. htp di nswt wsir $n b r-s t^{\ulcorner} w$ di prt-hrrw $k^{\complement} w 3 p d w$

2. ht $n b(. t) n f r t{ }^{\top} n h \underline{h}$ tr im $n k 3 n \underline{t} \underline{t} \underline{t}$

3. $h t h w n$.k mi $n b n h h$ in it senh $r n$

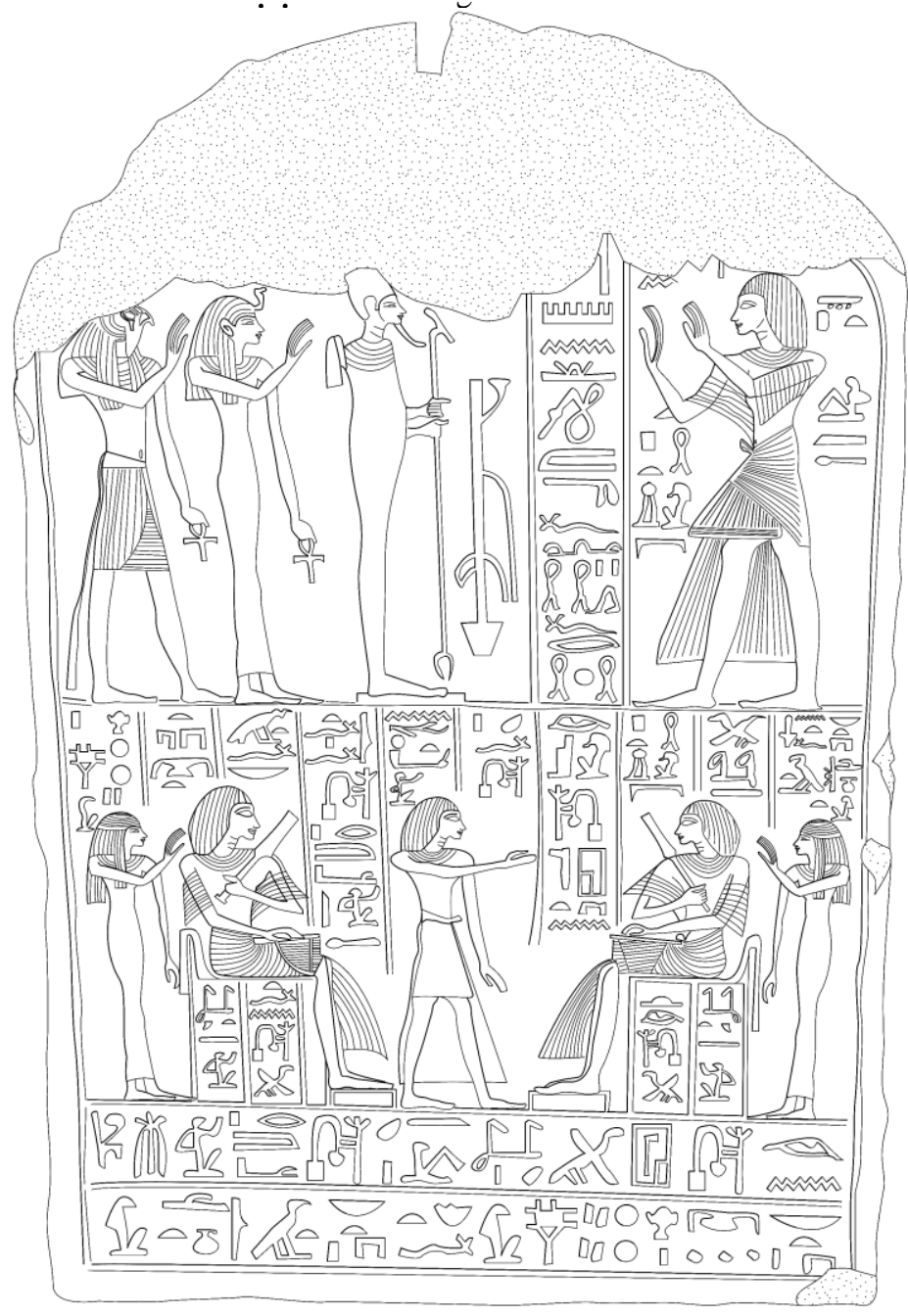

Fig. (3) Facsimiles of stela Sr. 14170

1. An offering which the king gives and Osiris(a), lord of Rastu $^{(b)}$, may they give a voice offering, loaves of bread, beer, oxen, fowl, [alabaster].

2. and every good things, $\mathrm{O}$ god who lives there into the ka of Theathen $^{(\mathrm{c})},[\ldots]$.

3. behind, your protection like the lord of eternity, by the father your name will revive ${ }^{(d)}$. 


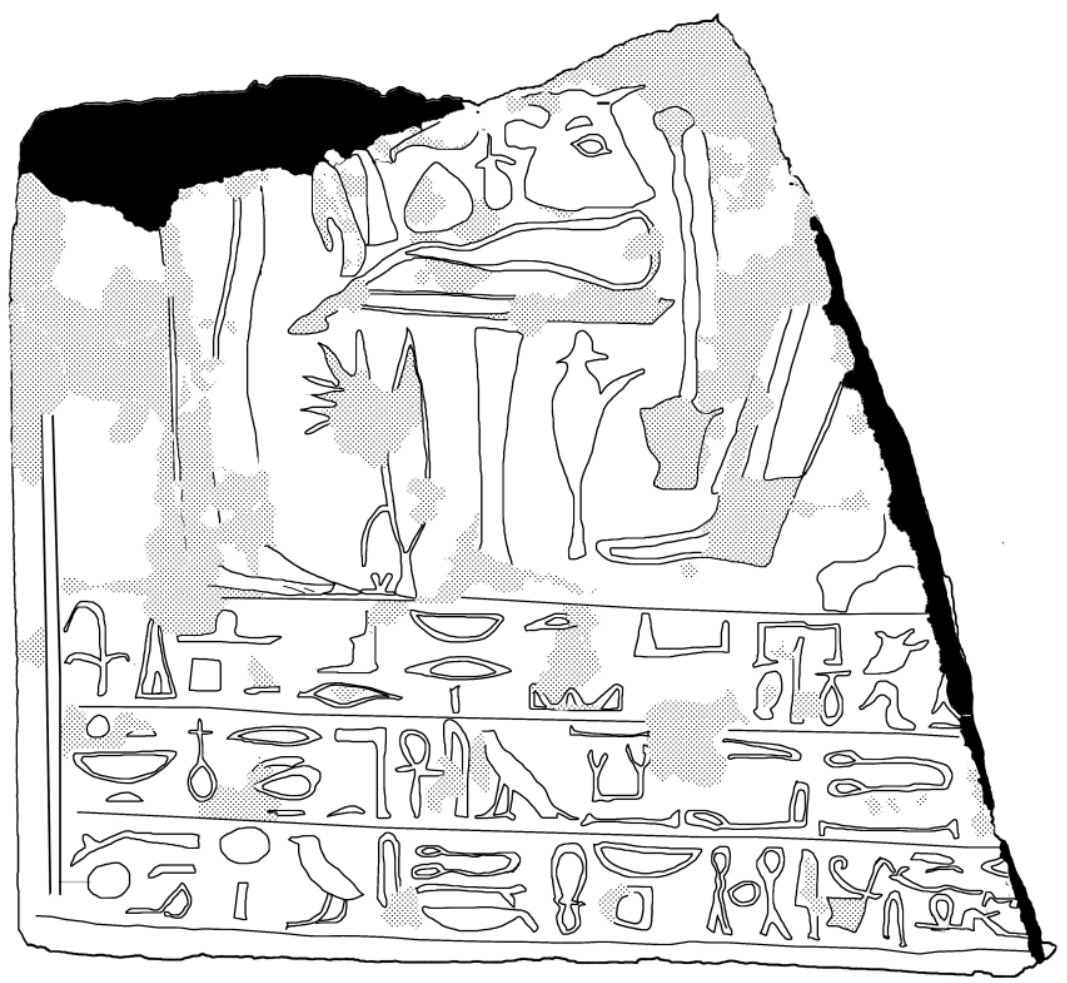

Fig. (2) Facsimiles of stela Cairo sr. 10322

(a) The arrangements of the offering formula is attested in the texts from 12 dynasty ${ }^{3}$.

(b) For the common title of Osiris $n b r 3-s \underline{t 3 w}$, see LGG. III, 681

(c) The personal name is not attested in Ranke, $P N$

(d) It seems to be the owner dead before his father, so the ritual for reviving the name will be procedure by the father, for the $s^{r} n h \mathrm{rn}$, see GM 121,1991 p. 69ff.

This Part of a private stela, with unknown owner, and unknown provinces, housed in the Grand Egyptian museum at Giza, Remarkably, the inscriptions, and the scenes are executed in sunken relief, facing to the left side, probably it is dating to the new kingdom

${ }^{3}$ W. Barta, Aufbau und Bedeutung der altagyptischen Opferformel, AF 24, Gluckstadt, 1968, p. 53 


\section{III- The Second Fragment (PI. (3))}

This stela which in the form of the false door ${ }^{4}$ Sr.10220 is made of colored limestone. Its dimensions are as follows: length $43.5 \mathrm{~cm}$; width $10.1 \mathrm{~cm}$ and thickness $56.6 \mathrm{~cm}$ (cf. fig. 1 and $\mathrm{Pl}$. A) ${ }^{5}$. The reliefs and hieroglyphs are in a very badly worn. The top-most of the lintel (a) which usually displays a single line of inscription containing the Offering formula has worn away.

Despite the Museum archive doesn't give enough information about it, addition to the visible surface-erosion on its inscriptions, it includes a clear indications to its owner Huy who bore the title of "scribe of the royal table". Unfortunately, the name of his wife is removed by scraping and pitting that happened on the surface. Moreover, the texts don't include any of the kings' names, which is one of the most helpful methods to date the finds. However, based on Certain features of all postures of Huy, his wife and the priest before him confirm with no doubt a date in the New Kingdome. Dating criteria is executed in all of the curled and braided wigs ${ }^{6}$, a long pleated kilt, the legs of the chairs that are formed in the shapes of the

${ }^{4}$ CG. 34052

5 I would like to express my deepest thanks and gratitude to Dr. T.S Tawfik, former Director of the Grand Egyptian Museum for permission to publish these pieces and for providing me with study assistance in the Museum.

${ }^{6}$ See for example the Tomb of Weserhat at Thebes, Davies, G., The Rock-Cut Tombs of Sheikh Abd El Qurneh, at Thebes, The Metropolitan Museum of Art Bulletin, 6, (1911), Figs 7-8. Mackay, E., On the Various Methods of representing hair in the WallPainting of the Theben Tombs, JEA , 5 (1918), Pp.113-116.; Younis, A., A stela of the Chief of the Workshops of Amun Pashed, Journal of the Faculty of Archaeology, Cairo, 2009, p.5. Seele, K., The Tomb of Tjanefer at Thebes, OIP, LXXXVI, PL. 17- 22. Moursi, M., Two Ramesside stelae from Heliopolis, GM 150 (1988), PL. 1. 
lions' legs upon a simple base, the style of the censer which is holding by the priest, and the shape of the offering table in which the circular loaves of bread are placed.

Off note, the upper part of the stela was completely destroyed with any remains of reliefs except the remains of the deceased's feet, facing left in worshiping position before Osiris who setting on his throne and his foot resting on the $m 3^{\mathrm{C}} \mathrm{t}$ sign $\ulcorner$ and the stand of the offering table remains between them.

On the other hand, the lower part displays Huy setting on a low backed chair facing right wearing a long pleated kilt and a broad collar. Also, he wears a wig with a heavy side-lock and holds by his right Kherp-specter while his left is extending towards an offering table in $h t p$ form plentifully provided with various kinds of provisions before him. Below it there are a four jars of bear in cone form. Beside him his wife setting on a low backed chair with her left arm around his right shoulder while her right is extending before. She wears a long tightfitting dress reaching to mid-calf, curled and braided wig. In front of them the funerary priest standing upright with one arm raising up while the other holding the censer of Horus. He wears a leopard skin over a short skirt.

Worth to mention, the attempts tried to know who was exactly the owner of this stela is more difficult to determine. Ranke mentioned many sources belonged to three nobles, all of them named Huy during the New Kingdome ${ }^{7}$. The First one was the troop commander of the army during the reign of Amenhotep the first ${ }^{8}$.

\footnotetext{
${ }^{7}$ Ranke, Die ägyptischen Personennamen, I, p.233.

${ }^{8}$ See his false door in the Egyptian Museum with TR 5.11.24.9. For it's publication see, Lowle, D., A. Funerary Stela of the Troop-commander of the Army and stander Huy, SAK, 9 (1981), Pp.253-258.
} 
The second Huy is known through a broken Limestone statue N. 2087 in Berlin. The accompanied text reads: "The royal Scribe of Lord of the two lands" ${ }^{9}$. The third Huy was the Waeb-priest of Webwawt ${ }^{10}$.

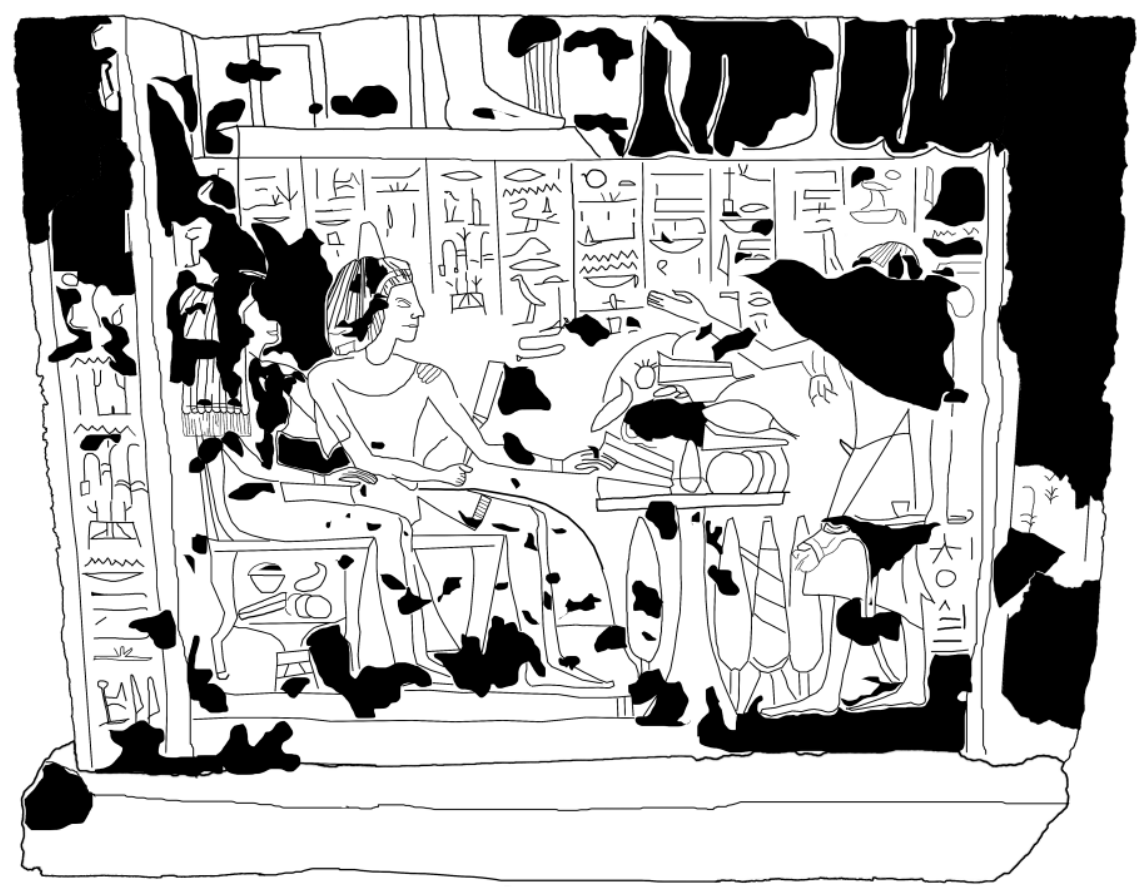

Fig. (1) Facsimiles of stela Cairo Sr. 10220

Finally, through comparing the title that it is recorded in our stela with all sources mentioned by Ranke we can note that the owner of the stela under study is not one of those who mentioned above. Further, the family of the owner, his father, mother, brother, and his sisters are missed in the Berlin statue.

${ }^{9}$ The same title is occurred in the left jamb (b). See for this Limestone statue, Roeder, G. Aegyptische inschriften aus den Königlichen museen zu Berlin, J. C. Hinrichs'sche Buchhandlung, Leipzig, 1913, n. 2087.

10 See his funerary stela in the archaeological Museum in Al Salam School at Assiut with inventory numbers 193. 
Through the investigation of the title which is bearing by the Owner of the stela understudy, we find that the name of " $h j$ " is recorded on the stela that has the number CG. $34090^{11}$ as a brother of $443 \div y^{\circ} " j w . t "$ who bear the same title of Huy "the scribe of offering table", If we assume that Huy who recorded without the title on Cairo stela CG. 34090 is the same person of the stela Sr. 10220, and a youngest brother who inherit and bear the same title after his brother death, we can probably reconstructed his family as:

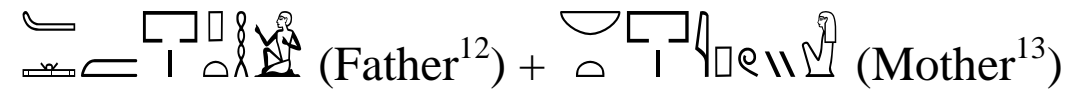

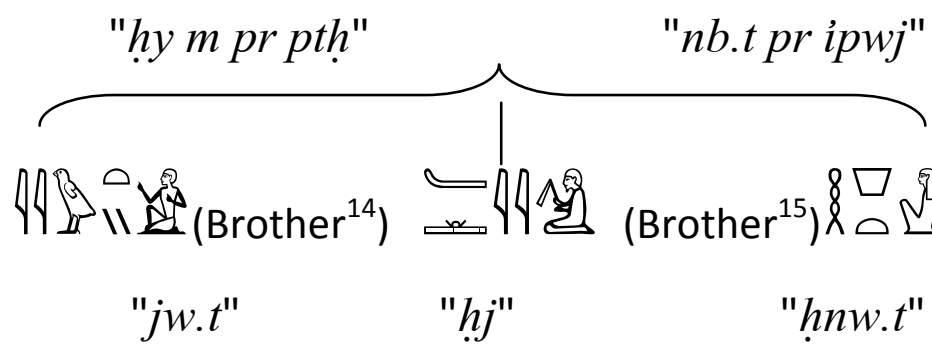

The scribe of the offering table

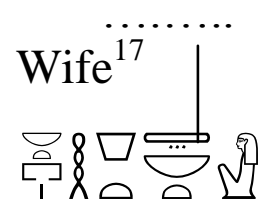

of the two lands

Wife

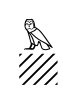

"nb.t pr ḥnw.t nb.t t3"

\section{The left jamb (b)}

${ }^{11}$ Lacau, Steles du Nouvel Empire, le Caire, 1909, p. 139-140

${ }^{12}$ Ranke, $P N$, p. 234,13

${ }^{13}$ Ibid. p. 24,1

${ }^{14}$ It is not attested in Ranke, $P N$

${ }^{15}$ Ibid. p. 233, 18

${ }^{16}$ Ibid. p. 242,18

${ }^{17}$ It is not attested in Ranke, $P N$ 
This jamb contains a single horizontal line of incised inscription which runs from up to dawn as follows:

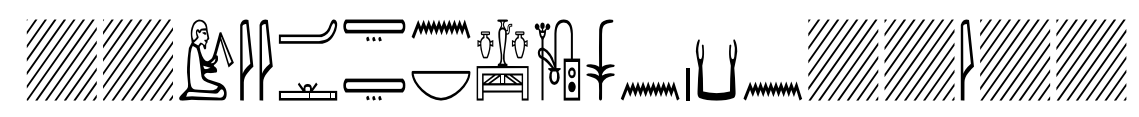

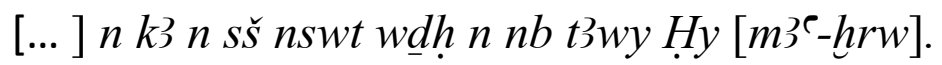

[....] into the ka of the royal scribe who place offerings before the lord of the two lands ${ }^{(a)}$, Huy ${ }^{(b)}$, justified.

(a) This epithet can be translated as "The royal scribe of the offering table(s) of the lord of the two lands"18, it is attested firstly in the Old Kingdom ${ }^{19}$. and mentioned frequently on the stela of the new kingdom: Stela Cairo CG. 34090, CG. 34176, CG. 34181, CG. 34177, CG. 34178, CG. $34180^{20}$

(b) The name of the priest is attested in Ranke, PN. I, 233

\section{The right jamb (c)}

This section has suffered extensive damage such as surface-erosion, scraping and pitting whereby all sings are completely lost. It more possible bore the offering formula combined by the official title of the owner, traces of the texts can be made out on the lower hand side, for examples of this kind of the decoration during the New kingdom see CG. 34049, CG. 34050, CG. 34054, CG. 34055, CG. 34056, CG. $34182^{21}$

\section{The panel (D)}

${ }_{18}^{18}$ AEO 1,p.30* [99]; LEM S.499 $(10,4)$

19 Dilwyn Jones, An Index of Ancient Egyptian Titles, Epithets and Phrases of the Old Kingdom, Oxford : Archaeopress, 2000, p.846

${ }^{20}$ Lacau, Steles du Nouvel Empire, le Caire, 1909

${ }^{21}$ Lacau, Steles du Nouvel Empire, le Caire, 1909 
The text above the owner and his wife contains an incised inscription of five vertical columns divided by a separated lines and read from left to right. The two columns accompanied the wife is partly worn away.

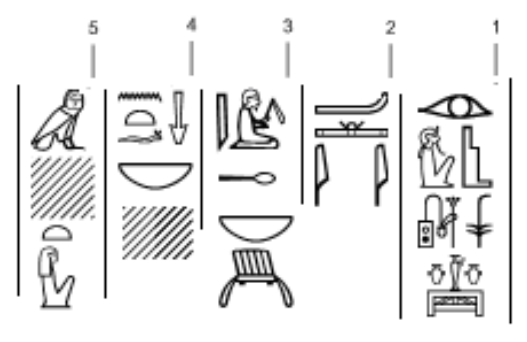

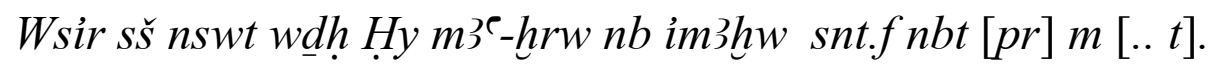

Osiris, the Royal Scribe of the Offering table, Huy, justified, possessor of reverence ${ }^{(a)}$, his siste ${ }^{(b)} r$, lady of [the house] $\mathrm{M}[. . \mathrm{t}]$.

(a) The non royal epithets $n b i m 3 h w$ is cited from the Old Kingdom $^{22}$ for this title in 12 dynasty, see D. M. Doxey, Egyptian Non-Royal Epithets in the Middle Kingdom. A Social and Historical Analysis, Leiden - Boston: Brill, 1998, 100-102.

(b) snt. $f^{\prime \prime}$ his sister", indicating to his a wife ${ }^{23}$.

The text above the priest contains an incised inscription of six vertical columns divided by separated lines and read from left to right as:

${ }^{22}$ Dilwyn Jones, An Index of Ancient Egyptian Titles, p. 478

${ }^{23}$ Wb. IV, 151 (5). 


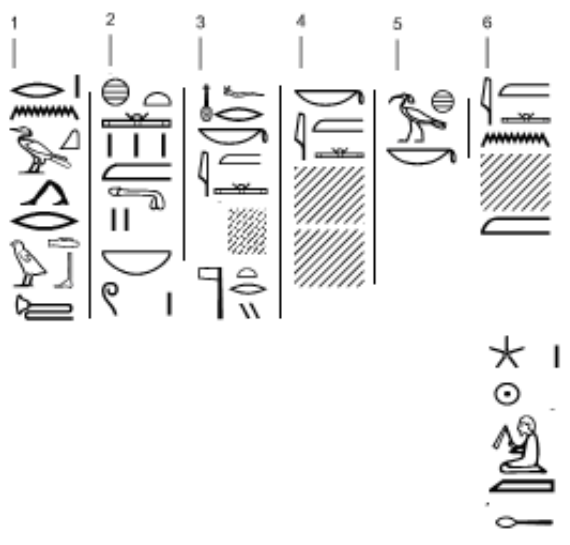

$r n\ulcorner k r w \underline{d} b-i h t m-b 3 h$ nbw nfr.k im [...] ntry.k im [...] 3h.k im [...] $m d w 3$ Hy m3-hrw.

Formula for entering into the reversion-offering from all [what are] before, may you be beauty with [...], may you be sacred with [....], may you be glorify with [...] in the morning, Huy, justified.

There is no conclusive evidence for dating this fragment of the stela, but through the analysis of the clothing style of the owner and his wife, the scent-cones, and the inscriptions is dating to the second part of 18 dynasty and probably to Ramesside period depending on his Berlin statue 2087, reconstructed family, and his title that frequently attested in this period. Also by the comparison of the decoration style and the careless executing of texts, we can say that the Stela Sr. 10220 and CG. 34090 came from one workshop at Abydos. 


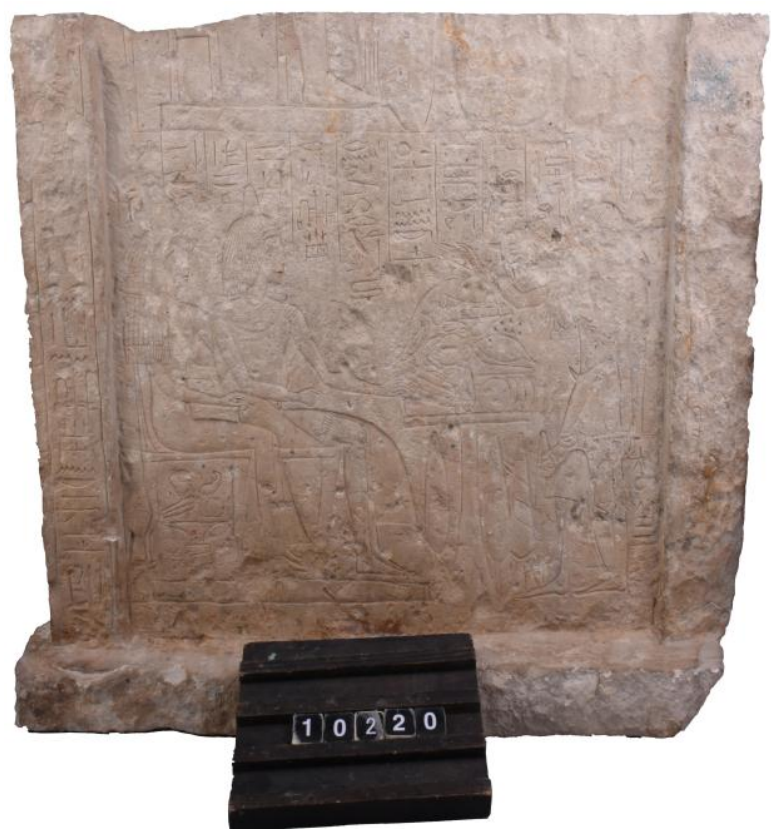

PI. (1) Stela, Cairo Sr. 10220 (Photograph by the author)

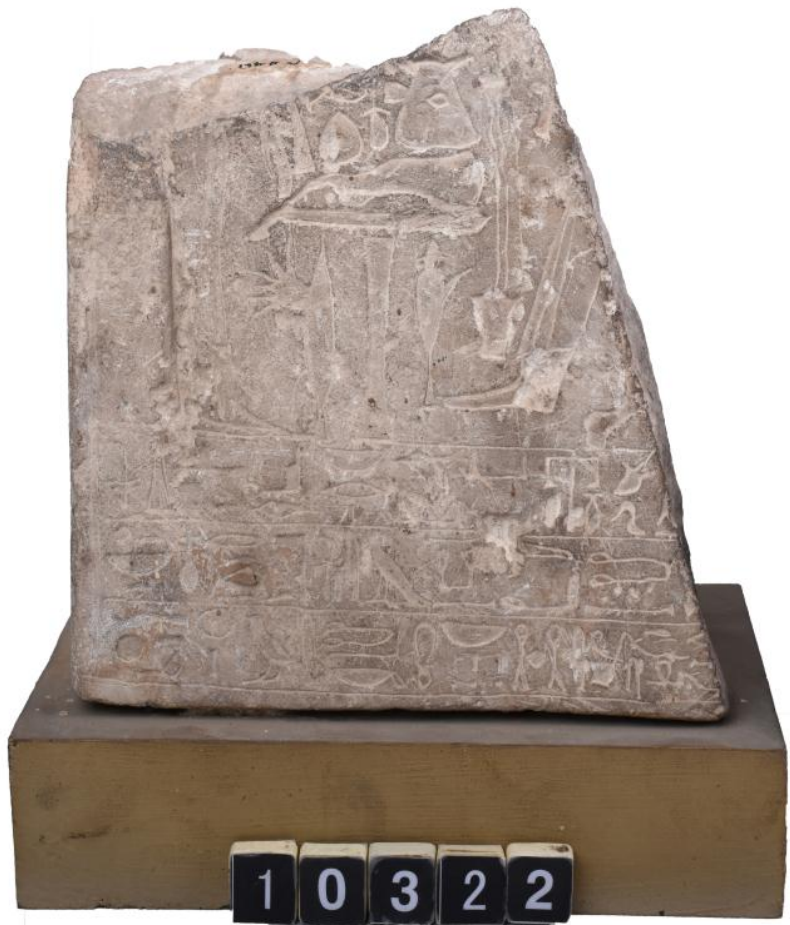

PI. (2) Stela Cairo Sr. 13937 (Photograph by the author) Dr.Eman AbouZaid 


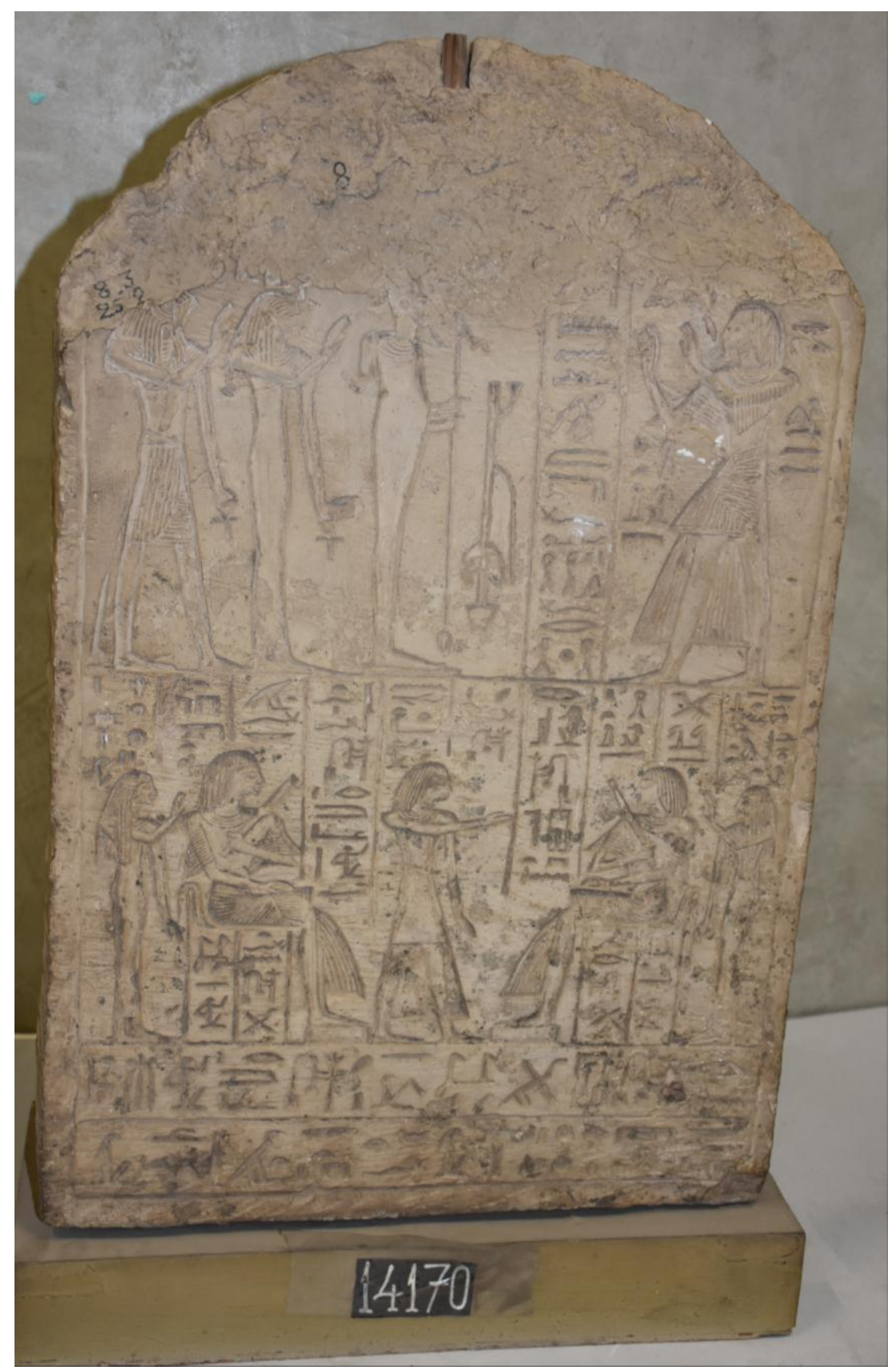

PI. (3) Stela Cairo SR. 14170 (Photograph by the author) 